\title{
MARGINALISASI MASYARAKAT ADAT
}

\section{Oleh: Djaja Hendra*}

\begin{abstract}
Entering the 21st century this far, discourses of adat communities is resurfacing. They are presented because the peoples' basic rights and ownership over agricultural resources are disturbed and trembled by the greediness of the ruling regime. In the midst of their powerlessness they are expelled from their socio-cultural attachment, and even more they are wiped out from the population map of a nation. But every regime always bring their own interpretation that leads to the elimination of the recognition of indigenous peoples. Transition of regime to Indonesians does not necessarily change the mentality and the culture that have been firmly embedded (embeddedness), but rather the new regime acts, without any embarrassment and awkward feelings, as successor in the marginalization of the adat communities and inherently their agrarian resources. Actually it is a "misguided thought" of the regime over their own adat communities. The implication therefore indicates that it is a necessity that the existence of indigenous peoples means, at the same time, the recognition of social relations in the society, the nation and the state.
\end{abstract}

Key Words: Adat communities, agrarian resources, false consciousness, misguided thought

\section{Pendahuluan}

Deru mesin pembangunan mulai bergemuruh ketika rezim Orde Baru berkuasa. Rezim yang mengawali pembangunan dengan modal hutang melalui penanaman modal asing (UU No.1/1967) membuka babak baru perwajahan Republik saat itu. Rezim dengan dan atas nama pembangunan berhasil menggoncangkan kehidupan harmonis masyarakat termasuk masyarakat adat dengan sumberdaya agrarianya. Bagi masyarakat adat sumberdaya agraria adalah andalan dan survivalitas kehidupan mereka sepanjang masa. Suatu anak bangsa diakui eksistensinya manakala mereka berdaulat atas dirinya. Kedaulatan dan eksistensi itu, kata Karl Marx, merupakan bentuk kesadaran diri dan sekaligus harga diri ketika diperhadapkan dengan pihak lain. Oleh karena itu, menjadi tidak dapat diterima ketika sumberdaya agraria yang telah menghidupi sepanjang hayat dan bergenerasi hingga merupakan bagian sosiokultural tiba-tiba diklaim sebagai bukan milik mereka.

Dalam derap roda pembangunan masyarakat adat diajarkan nalar-nalar pembangunan seperti, "demi kepentingan rakyat banyak" dan juga tatanan mengenai 
$16 \quad \begin{aligned} & \text { JURNAL ILMIAH MIMBAR DEMOKRASI } \\ & \text { VOLUME 13, NOMOR 2, APRIL } 2014\end{aligned}$

“Hak Menguasai Negara (HMN)". Namun pelajaran itu tidak tuntas karena mereka tidak tahu siapa rakyat banyak itu dan siapa pula negara. Oleh karenanya gangguan akan kedaulatan dan eksistensi tidak saja menimbulkan resistensi bagi masyarakat adat tetapi juga melahirkan beragam bentuk perlawanan.

\section{Sejarah Lahirnya Masyarakat Adat}

Dalam perspektif keindonesiaan istilah adat atau masyarakat adat muncul atau dimunculkan pertama kali oleh pemerintah kolonial Belanda. Istilah tersebut ketika Indonesia masih bersifat nation dan dalam suasana kebatinan alam Nusantara, sungguh tidak dikenal (Bachtiar 1976: 7). Pada masa itu nation memiliki otoritas dan kedaulatan sendiri dan kedudukan mereka satu sama lain dalam posisi equal dan saling menghormati sejauh hak dasar antarmereka tidak saling dianeksasi. Tidak bisa lain bahwa, munculnya istilah adat yang hakikatnya menunjuk pada nilai-nilai dan normanorma yang hidup dalam suatu masyarakat yang bersangkutan, merupakan rumusan yang sedikit-banyak tertata, baku dan ajeg sehingga dapat didokumentasikan berupa budaya lisan, folklore atau dalam bentuk tertulis. Dokumentasi-dokumentasi inilah yang dijadikan rujukan-dasar bagi keberlakuan maupun kekuatan mengikat dan dihayati, hanya bagi masyarakat yang memiliki nilai-nilai dan norma tadi. Jadi istilah masyarakat adat dengan hukum adat, atau tepatnya masyarakat hukum adat merupakan satu koin dalam dua sisi. Dengan menunjuk pada proses-kejadian maka tidak bisa lain bahwa keberlakuan dan kekuatan mengikat maupun penghayatan-penghayatan itu bersifat lokalitas.

Paparan di atas nampaknya dijadikan dasar oleh pakar hukum adat kolonial van Vollenhoven dan merupakan orang pertama yang mengemukakan bahwa, setiap anak negeri di Nusantara yang beraneka itu tentulah pula memiliki hukumnya sendiri. Itulah sebabnya van Vallenhoven membagi Indonesia menjadi 19 kukuban-kukuban hukum adat (rectskringen), dengan didasarkan atas nilai-nilai dan norma yang dikandungnya. Van Vollenhoven menyebut bahwa kukuban hukum (menunjuk pada adanya perbedaan sosiologis-pen) adat dengan tekanan yang berbeda antara satu kukuban dengan kukuban hukum lainnya. Kukuban hukum (adat) masyarakat Aceh-Gayo misalnya berbeda dengan Bangka-Belitung atau dengan kukuban masyarakat hukum (adat) Riau, meski mungkin dalam konstelasi kebahasaan di antara mereka ada kesamaan yaitu berbasis bahasa Melayupasar.

Demikian pula elemen seperti marga dalam kukuban hukum adat 
Palembang dengan ulayat di Minang misalnya, meski memiliki persamaan tetapi tidak kurang dalam praktik akan nilai-nilai dan norma tadi terdapat pula perbedaanperbedaan, demikian seterusnya. Belakangan penetapan itu mendapatkan kritik dan ditolak oleh tokoh agraria AP Parlindungan (Prisma, 4, 1989: 5) dengan mengatakan bahwa kukuban hukum adat yang dikemukakan van Vollenhoven bersama muridnya Ter Haar bukanlah didasarkan atas kajian empirik memadai melainkan hanya sebuah hipotesis sehingga kesahihan dan keakurasian yang merupakan potret masyarakat hukum adat Nusantara itu sesungguhnya patut diragukan. Dengan kata lain bias Barat menjadi tak terhindarkan.

Saya mencoba untuk mengikuti aliran pemikiran ini yaitu dengan menelusuri dan menggiring ke tema tulisan, "Marginalisasi Masyarakat Adat" dengan catatan bahwa, untuk tidak terlalu jauh memberikan tafsir dan tekanan berlebih berdasar perspektif sosiologis. Jika sebaliknya --sedikit gambaran saja-saya tidak ingin menerjemahkan adat dengan istilah lain-lain seperti indegenous dan lain sebagainya. Bagi saya istilah adat atau masyarakat adat adalah khas Indonesia dan memiliki keunikan tersendiri yang membedakan kita dengan orang asing lain ketika meneliti masyarakat kita, Indonesia. Oleh karena itu mengangkat isu masyarakat adat dalam tinjauan sosiologis dapat menjadi sangat panjang sehingga khawatir bertabrakan dengan teknis keterbatasan ruang dalam jurnal ini.

Masyarakat Adat dalam Konstelasi

\section{Regulasi Negara}

Penyebutan masyarakat adat atau lebih tepat disebut masyarakat hukum adat untuk pertama kali tercantum dalam UU No.5/1960 tentang Peraturan Dasar Pokokpokok Agraria atau singkatan resminya Undang-Undang Pokok Agraria (UUPA). Sebutan itu muncul dalam pasal 2 ayat 4 yaitu Hak menguasai dari Negara ... dan masyarakat hukum adat, menurut ketentuan-ketentuan Peraturan

Pemerintah. Pasal 3, dalam mengingat ketentuan-ketentuan dalam pasal 1 dan 2 pelaksanaan hak-ulayat dan hak-hak serupa itu dari masyarakat hukum adat, sepanjang menurut kenyataannya masih ada, harus sedemikian rupa....Sementara Aliansi Masyarakat Adat Nusantara (AMAN) dalam kongres I tahun 1999 menyebut masyarakat adat adalah: "Komunitas-komunitas yang hidup berdasarkan asal-usul leluhur secara turuntemurun di atas suatu wilayah adat, yang memiliki kedaulatan atas tanah dan kekayaan alam, kehidupan sosial budaya yang diatur oleh hukum adat dan lembaga adat yang mengelola keberlangsungan kehidupan masyarakatnya". Pasal 18 B ayat 2 UUD 1945 hasil amandemen ke-2 
$18 \quad \begin{aligned} & \text { JURNAL ILMIAH MIMBAR DEMOKRASI } \\ & \text { VOLUME 13, NOMOR 2, APRIL } 2014\end{aligned}$

dimunculkan lagi berbunyi, Negara mengakui dan menghormati kesatuankesatuan hukum adat beserta hak-hak tradisionalnya sepanjang masih hidup (pen.).

Penjelasan di atas terdapat perubahan tekanan tetapi memiliki arti sama terkait masyarakat (hukum) adat, yaitu sepanjang menurut kenyataannya masih ada (UUPA, 1960) maupun sepanjang masih hidup (UUD 1945 hasil amandemen). Menyusul penyebutan hak ulayat, turun temurun, wilayah adat dan sumberdaya alam merupakan tindakan sepihak dan membatasi seiring aliran politik hukum yang dipercayai sebagai basis ideologis yang dipeluk rezim. Pemikiran demikian dipertegas melalui Ketetapan MPR/IX/MPR/2001 yang membedakan sumberdaya agraria dengan sumberdaya alam. Perbedaan hakekatnya dipinjam dari pemerintah kolonial ketika menyebut luar Jawa dengan hak konsesi berkenaan dengan sumberdaya alam. Ruh ini diadaptasi dan dituang-utuh sebagai istilah "Hak Menguasai Negara (HMN)" dalam undang-undang kita. Prinsip HMN bahwa, semua wilayah luar Jawa dianggap tidak bertuan dan karenanya kepemilikan tunggal sepenuhnya dalam penguasaan pemerintah kolonial yang berpusat di Batavia.

Di Jawa sendiri karena lebih dominan tanaman hortikultura maka UU pengatur pun berbeda yaitu Agrarische Wet atau dikenal undang-undang pokok tentang tanah (pertanian termasuk perkebunan). UU ini dipaksa lahir, pascatanam paksa (1870), oleh elit politik bercorak liberal di negeri Belanda guna mengeruk keuntungan sebesar-besarnya di negeri jajahan. Agrarische Wet intinya adalah menjamin tanah-tanah bagi pengusaha-pengusaha Belanda. Serangkaian pasal Agrarische Wet yang bermakna penindas ini justru diambil-penuh dan diwujudkan dalam pasal-pasal UUPA 1960 dengan penamaan berbeda, seperti eigendom menjadi Hak Milik, erfpacht menjadi Hak Guna Usaha (HGU) dan seterusnya. Bisa jadi jalanpintas itu secara politik hukum agraria tidak bermasalah tetapi harus diakui bahwa setiap pasal tentu memiliki kandungan sosiologisnya sendiri-sendiri dan berujung pada siapa rezimnya.

Setelah merdeka secara politik, perilaku rezim yang berkuasa di negeri ini ternyata "setali tiga uang" dengan pemerintah kolonial. Bahkan jika ingin dikatakan lebih jujur bahwa penyebutan istilah adat dalam pengertian kolonial yaitu, asli. Kata ini secara jelas tercantum dalam pasal demi pasal maupun Penjelasan dalam pasal demi pasal terutama ketika membicarakan Presiden dalam UUD 1945. Kita kutip fasal 51 dari Wet op de Indisch Staats inrichting van Nederlands-Indie ayat 3, Gubernur Jenderal dapat 
menyewakan tanah .... Dalam peraturan ini tidak termasuk tanah-tanah yang telah dibuka oleh rakyat asli atau digunakannya .... ayat 5, Gubernur Jenderal menjaga jangan sampai pemberian tanah itu melanggar hak rakyat asli. Ayat 7, Tanahtanah yang dimiliki rakyat asli dapat diberikan kepada mereka itu dengan hak eigendom, yakni mengenai kewajibankewajiban pemilik kepada negara dan desa; dan pula tentang hak menjualnya kepada orang lain yang tidak termasuk golongan rakyat asli. Ayat 8, Persewaan tanah oleh rakyat asli kepada orang-orang bukan rakyat asli berlaku menurut peraturan perundang-undangan (Radjagukguk, 1979: 7).

Artinya, dalam rentang panjang regulasi keagrariaan di Jawa maupun luar Jawa bahwa tidak ada sesuatu yang nyata berbeda. Prinsip-prinsip kolonial tentu saja bertolak dari cara berpikir yang menguntungkan negara "induk" Belanda. Siapa peduli dengan urusan nation dan beragam adat di negeri jajahannya. Keanekaan justru mempermudah rezim melakukan politik "belah bambu" yaitu dengan mengangkat yang satu tetapi dengan menginjak lainnya. Cara ini juga dicontoh rezim menjelang kejatuhan rejim Orde Lama hingga mewujud UUPA dan diteruskan rezim Orde Baru dengan gelar karpet merah buat modal asing maupun rezim Reformasi yaitu menerobos melalui
Tap MPR, UU hingga ke UUD 1945 yang diamandemen.

Rezim yang berkuasa menggunakan cara berpikir logis-rasional yang dipinjam utuh dari pemerintah kolonial. Rezim dalam praktik pemerintahan layaknya negeri jajahan yang berpusat di Jakarta, luar Jawa dengan hak konsesi, sementara di Jawa dengan agrarische wet. Adakah perbedaannya? Rezim berkuasa dengan pemerintahan dan kebijakan nampaknya puas dengan perilaku mirip kolonial tanpa perduli bahwa yang ditindas adalah anak bangsa sendiri. Semua yang datang dari kolonial dicitrakan sebagai baik dan benar, diidolakan sehingga didudukkan sebagai orang terpandang, intelek dan memiliki derajad sosial tinggi. Perilaku ini selanjutnya diakulturasikan dalam kultur dan mental kehidupan dalam berbangsa dan bernegara hingga mewujud menjadi ideologi yang secara sadar meransek ke UUD 1945 yang diamandemen tadi.

Jelas bahwa cara berpikir demikian sesat atau sesat pikir. Mereka silau. Mereka dengan kesadarannya, berpikir terbalik. "Kesadaran palsu" jadi sebuah kebenaran nyata. Bagaimana mungkin masyarakat adat, sepanjang masih hidup, sepanjang masih ada, itu sama artinya atau bermakna sama dengan, suatu ketika bakal tidak ada. Cara berpikir dengan membandingkan masyarakat adat disamakan dengan rumah adat, atau 
pakaian adat memang tidak dipungkiri dapat punah dan berganti dalam bentuk baru, atau sama sekali berbeda dari wujud aslinya. Cara berpikir dengan menempatkan masyarakat adat sama dengan hasil karya manusia. Keterlekatan masyarakat adat dengan sosiokulturalnya (baca: masyarakat agraris) tidak akan mati. Dia terus hidup. Matinya masyarakat adat sama dengan matinya NKRI ini.

Prinsip atau konsep bahwa masyarakat adat adalah masyarakat yang terikat sosiokulturalnya dan sosiokultural mana merupakan adaptasi dengan sumberdaya agrarianya. Pemahaman dan pemaknaan akan sumberdaya agraria adalah bumi, air dan ruang angkasa itu serangkaian dengan di atas bumi/tanah, di dalam (perut) bumi, goa; air termasuk sungai, danau dan terutama laut beserta kandungan didalamnya merupakan konsep hidup yang lengkap dan kaya. Sehingga habisnya sumberdaya agraria itu, menyusul matinya masyarakat adat. Mungkinkah?

Tambahan lanjutan bahwa cara berpikir demikian semakin lengkap melalui konsep-konsep yang dihadirkan. Penyebutan "agraria" yang disinonimkan dengan tanah/lahan pertanian juga menyesatkan. Kenapa harus mempersempit istilah jika kita sendiri memiliki nama yang justru mampu menampung seluruh substansi keagrariaan yang ada, dan bersesuaian dengan kondisi di negeri kita yang kaya serta cocok dengan sosiokultural anak bangsanya. Artinya ketika kita mengangkat isu keagrariaan adalah juga membicarakan sumberdaya agraria yang memberikan jaminan hidup kepada anak bangsa termasuk masyarakat adatnya. Oleh karena itu, menjadi terasa aneh jika kita sendiri berusaha mempersempitnya hingga berimplikasi pada konsep yuridis formal yang menjauhkan dari sosiokultural masyarakatnya. Di sini saya ingin mengatakan bahwa konsep sumberdaya agraria adalah khas Indonesia. Menyangkut kekhasan itu maka dipastikan bahwa di negara lain termasuk kolonial bertalian dengan kepemilikan atas sumberdaya agraria-sumberdaya agraria tidaklah selengkap kita. Jadi ke depan tidak perlu dan tidak ada lagi urgensitas penyebutan tanah/lahan diartikan sebagai "agraria dalam arti sempit”.

\section{Rasionalisme Pemarjinalan Masyarakat Adat}

Dengan menelusuri peran rezim melalui aktor-aktornya justru menunjuk perilaku aktor dan ideologi (aktor) yang dianut. Terkait masyarakat adat dimana mereka menempatkan terpisah dari masyarakat pada umumnya alih-alih menunjuk posisi berada di atas warga masyarakatnya. Padahal ideologi rezim dapat berbeda dengan ideologi negara, katakanlah ideologi rezim dapat bersifat 
otoriter, atau demokratis atau variasi antara keduanya (Budiman 1996: 87). Untuk kasus Indonesia, ideologi negara dengan sangat jelas menempatkan Pancasila sebagai ideologi negara dan tujuan negara tercantum dalam Pembukaan UUD 1945 yang terinci dalam pasal demi pasal UUD tersebut.

Dalam praktik kenegaraan baik masa Perjuangan, Orde Lama maupun Orde Baru praktik ideologis rezim dipandang terlalu kuat. Mereka menafsir pasal demi pasal dalam UUD 1945 sebagaimana tersurat sehingga belakangan dianggap melenceng dari ketentuan yang tersirat. Keterlalu-kuatan demikian dianggap melampaui kewenangan hingga karenanya melahirkan benih-benih penolakan. Tidak total (revolusi) memang. Tetapi perlu pembaruan-pembaruan dengan tanpa merubah maupun membentuk struktur baru dari kelembagaan yang sudah ada, atau dikenal dengan reformasi. Langkah yang bertujuan "menyeimbangkan" antara kekuasaan eksekutif dengan kekuasaan legislatif serta memperkuat yudikatif hingga perlu UUD 1945 itu diamandemen.

Dalam perkembangan demikian tentulah negara harus bersikap hati-hati memaknai masyarakat adat. Tidak cukup dengan hanya sekadar pemahaman luar belaka tanpa menyelami lebih dalam akan karakteristik setiap masyarakat adat yang ada. Pemahaman dan pemaknaan menjadi sangat esensial dan krusial agar tidak terjadi salah-paham. Mungkin masyarakat adat yang sekarang tidaklah memiliki pengaruh sekuat dibanding beberapa daerah yang berbasis etnik berbalut desentralisasi (otonomi daerah) ketika itu. Tirtosudarmo (2004) menggambarkan terbentuknya Provinsi Kalimantan Tengah. Bahwa provinsi terlahir dari tekanan elit politik Dayak kepada Presiden Soekarno. Kegelisahan akibat tergesernya mereka dari sektor ekonomi maupun politikbirokrasi pemerintahan oleh suku Jawa, Banjar dan sedikit Melayu hingga karenanya pada bulan Mei 1957 Presiden memutuskan pembentukan provinsi Kalimantan Tengah bagi orang Dayak. Tjilik Riwut seorang Dayak Ngaju sebagai gubernur pertama.

Hal ini, tidak berbeda dari hasil pengamatan saya ketika berkunjung di Kabupaten Mentawai tahun 2010. Sebelum berstatus kabupaten, wilayah ini berbentuk kecamatan. Rakyat menuntut dijadikan kabupaten alih-alih otonomi, putra daerah dan disinggung sedikit isu SARA (agama) untuk lepas dari penguasaan Kabupaten Padang Pariaman Sumatera Barat. Terbukti bahwa bandul kekuasaan mulai beralih terutama jabatan birokrasi yang semula diisi intelektual Minang digantikan putra daerah Mentawai dengan cara-cara membelakangi logika birokrasi yang 
22 JURNAL ILMIAH MIMBAR DEMOKRASI

berlaku. Alhasil, kabupaten Mentawai adalah salah satu kabupaten yang mendapat rapor merah dari seluruh kabupaten pemekaran akibat ketidakbecusan dalam memajukan wilayah otonomi sesuai pembentukannya.

Unger (2007: 11-3) menyebut bahwa sosok ideologi rezim biasanya mengambil salah satu dari dua prosedur, yaitu: analisis logika atau penjelasan "kausal" (sebab-akibat). Biasanya prosedur berupa analisis logika atau rasionalisme yang dipilih (dilawankan dengan historisme). Analisis logika menunjuk pada premis-premis yang didasarkan atas kekuatan eksplanatoris bukan pada akurasi deskriptif dalam kesimpulan-kesimpulan yang dihasilkan. Analisis ini bekerja lewat proses deduksi-logis, dan perbaikan konsep secara berkesinambungan, serta memasukkan asumsi empiris tentang alam dan manusia. Analisis ini mengandung prinsip proporsional dengan segala interdependensinya yang diatur oleh gagasan-gagasan sebab, konsistensi, dan kontradiksi yang logis dan tepat.

Keseluruhan pikiran bergerak ditataran hipotesis, yaitu kesimpulan benar secara deskriptif hanya untuk taraf premis yang dipegangnya. Dengan mengendurkan premis-premis tersebut maka yang terjadi adalah, kompleksitas menurun dan akurasi ketepatan berkurang dari rasionalitas sosial yang ingin dipahami. Semakin besar kecenderungan pada kesederhanaan penjelasan, semakin besar pula ancaman bahwa kesimpulan-kesimpulan akan gagal diterapkan pada bidang apapun yang menjadi perhatian. Semakin condong kita kepada kebenaran deskriptif, semakin tinggi risiko dugaan-dugaan kita bakal tergelincir dalam suatu rangkaian proposisi terbatas dan rumit; sehingga kita bersikap adil dan keliru dengan kesan-kesan akal sehat kita sendiri.

Itulah sebabnya ketika rezim dengan ideologi yang dipeluk itu tetap kukuh dengan politik hukum agraria yaitu dengan menempatkan masyarakat adat yang nantinya akan mati, juga dalam konteks kekinian terutama masuknya modal asing maka kehadiran masyarakat adat di sana dianggap sebagai pengganggu atas pengolahan sumberdaya agraria khususnya sumberdaya alam. Oleh karena itu beragam strategi dilakukan agar masyarakat adat tidak betah dan secara sukarela meninggalkan sosiokulturalnya itu. Atau jika tidak maka dengan cara-cara kekerasan maupun memanipulasi regulasi berbasis Hak Menguasai Negara (HMN) tadi. Belakangan paradoks ketika membutuhkan devisa melalui pariwisata rezim sibuk mengangkat aneka budaya lokal atau segala sesuatu yang serba lokal. Padahal sesuatu yang bersifat lokal tidak terhindarkan selalu menjadi domain masyarakat adat. Jika demikian, negara 
khususnya rezim bak pepatah "menepuk air didulang”. Begitulah.

\section{Kesimpulan}

Posisi masyarakat adat dengan istilah "masih ada" atau "masih hidup" dalam konstelasi kehidupan berbangsa dan bernegara yang dipraktikkan ideologi rezim tidak saja menunjuk pada ketidakjelasan dan ketidaktahuan melainkan "sesat pikir" yang terlanjur jauh. Perihal tersebut dikuatkan dengan memisahkan sumberdaya agraria dengan sumberdaya alam dengan tujuan untuk 'merebut' yang dimiliki masyarakat adat melalui hak tradisionalnya berupa hak ulayat atau atas nama lain. Ideologi rezim dan komprador (pemodal asing) dalam mengimplementasikan tujuan-tujuan negara sesuai Pembukaan UUD 1845 dengan dasar ideologi Pancasila tetapi dalam praktik kenegaraan menggunakan cara berpikir melalui analisis logika hingga menempatkan masyarakat adat tidak berbeda seperti rumah adat, pakaian adat yang sewaktu-waktu bisa punah atau dapat dijadikan barang antik yang diperagakan di estalase museum-museum. Pengamandemenan UUD 1945 alih-alih memperjelas akan posisi masyarakat adat tetapi justru menjungkalkan masyarakat adat menuju jurang kepunahan. Sebuah "kesadaran palsu" yang berujung pada keterceraiberaian terhadap dan sesama anak bangsa.
Berdasarkan paparan ini maka sesuai judul dengan mengangkat tema "Marginalisasi Masyarakat Adat" sesungguhnya lebih tepat jika disebut sebagai, "Menanti Kepunahan Masyarakat Adat". Pilihan kalimat ini menunjuk pada, secara internal masyarakat adat itu sendiri yang "menghabiskan" dirinya sendiri tanpa campur tangan pihak eksternal termasuk negara. Atau, dengan hanya mendokumentasikan di dalam regulasi yang ada tetapi tanpa adanya perubahan atau tindakan-nyata sama sekali dari rezim, termasuk memberikan ruang atau akses hingga memungkinkan masyarakat adat kita itu dapat terus berkembang dan eksis maka patut pula dipertanyakan bahwa, apakah rezim berkuasa sedang "bermainmain" secara diskriminatif atas anak bangsanya sendiri seraya menangguk secara begitu rakus sumberdaya agrarianya. Ironis!

\section{DAFTAR PUSTAKA}

Bactiar, Harsja, W., "Masalah Integrasi Nasional di Indonesia". Prisma. Nomor 8, 1976.

Budiman, Arief, Teori Negara; Negara, Kekuasaan dan Ideologi. PT Gramedia. Jakarta, 1996.

Parlindungan, AP., "Politik dan Hukum Agraria di Zaman Orde Baru". Prisma. Nomor 4, 1989. 
$24 \quad \begin{aligned} & \text { JURNAL ILMIAH MIMBAR DEMOKRASI } \\ & \text { VOLUME 13, NOMOR 2, APRIL } 2014\end{aligned}$

Radjagukguk, Erman, "Pemahaman Rakyat tentang Hak atas Tanah". Prisma. Nomor 9, 1979.

Tirtosudarmo, Riwanto, "Masyarakat Adat, LSM dan Perebutan SDA: Sebuah

Pengamatan Awal di Kalimantan Tengah". Masyarakat Indonesia. Jilid XXX. Nomor 2, 2004.

Unger, Roberto, M., Teori Hukum Kritis. Nusamedia. Bandung, 2007. 